ることができた，また，画像の高分解能化にも応用可能であり，今 後は撮像部位ごとに細かく検討することにより画質の向上が可能で あると考える。

【結語】今回われわれは, SENSE法の基本特性を把握でき, 十分, 臨 床応用可能であることを確認できた。

\section{6 頭部二次検查におけるMRAの画質向上および有用性の評価} 釧路脳神経外科病院・放射線科 大西拓也, 岡 哲也, 古川研治 大野文江, 森本 守

【目的】近年，頭部血管性病変の検査に扔けるMRAの有用性が注目さ れており，血管性病変のルーチン検査として使用される機会が多く なっている。 そこで, ルーチンMRAにて血管性病変が疑われた場合 の二次的検查や微小動脈瘤の長期フォローを目的とした高分解能 3D-MRAの有用性を検討したので報告する.

【使用機器】Signa Horizon 1.5T (GE), 自作ファントム

【方法】1)撮像条件の設定 撮像時間短縮, 分解能の向上のためFOV $8 \mathrm{~cm}$ ，スライス厚 $1.2 \mathrm{~mm}$ ( $\times 4 \mathrm{ZIP}$ 使用), 収集マトリクス $128 \times 256$ (512ZIP使用), 撮像時間10分以内, 3DTOF使用とする. フリップア ングル TR 積算回数を可変とする. 自作ファントムにより上記の条 件を変化させ, 信号強度, ノイズ, スラブ内信号強度の均一性を視 覚的に評価する. 2) ファントムで決定した条件にて健常ボラティア のAcom, ICを撮像しワークステーションにてMIP, surface画像を作 成, 視覚的評価に有用性を検討する。

【結果】自作ファントムにてフリップアングル10degではコントラスト 低下により微小血管の描出が不良となり, 30deg以上では飽和が起こ るためスラブ内で抹消側の信号の低下が起こった．解析画像はボク セルボリューム減少によるノイズがみられたが，ルーチンでは困難 だった主幹動脈と分枝の分離が良好だった.

【考察】解析画像では，ノイズによる血管の不整がみられ，血管径計 測の信頼性は低いと思われるが, 血管構造の立体的観察を目的と した, 二次的検査や微小動脈瘤の長期フォローを目的とした検査に は有用性があると思われる。

\section{7 ultra fast 3DFSPGRを使用した頭部造影MRA}

聖隷三方原病院・画像診断部 栗田仁一，長屋重幸，斉藤 忍 野沢滋幸, 武田真典, 山岡真二, 天野智康, 湗田一十

【目的】脳動脈瘤の治療は現在Guglielmi detachable coil (GDC)を用い た塞栓術が広く用いられ，術後の経過観察にはおも㧍も，CT, MRA (TOF)が行われている. しかし, 金属アーチファクトの影響で塞栓 後の評価が困難であることが多く，このため現状ではX線DSAに頼 らざるを得ない. 当院では昨年よりultra fast 3DFSPGR を使用して おり, 従来法の3DFSPGRよりも, さらに短時間で撮像できるように なった. ultra rast 3DFSPGRでは短いTEを使用するためGDCによる susceptibility artifactsに画像が影響を受け難いと考えられる. 本研究 ではこの撮像法における至適撮像条件を求め, 臨床応用を行った。

【方法】磁化率の異なる物質として, 水, 希釈したGd造影剤, コイル を用いたファントムを作成し，各パラメータ（TR，TE， slab partition/ thickness, matrix等)の条件を変え, $\mathrm{C} / \mathrm{N} お よ ひ ゙$ susceptibility artifactsの 影響を調べ，至適撮像条件を検討する。

【結果】至適撮像条件は, TR/TE 4/0.9msec, 12slab partition/thickness (inplain ZIP4)， matrix 256*160，撮像時間 5秒であった。これによ り，動脈相をとらえ， susceptibility artifactsの影響の少ない画像が得 られ，塞检部の観察ができるようになると考えられる。

8 elliptical centric view orderingを用いた頭頸部造影MRA - 大動 脈に生じるアーチファクトの検討一 国家公務員共済組合連合会横浜栄共済病院・放射線科 高橋光幸 荒田光俊, 長谷川誠, 山之口稔/杏林大学·放射線医学教室 高原太郎 【目的lelliptical centric view ordering (以下, ECVO)はYZ平面におけ る位相エンコード順をk-spaceの中心から渦状に埋めていく方法であ $り$, 従来のcentric view orderingより撮影時間が延長しても静脈の描 出を抑制し得る特長がある，われわれは，本法を用いて頭頸部造影 MRAを施行したところ, 従来法では認めなかったアーチファクト (内頝動脈は造影されているのに対し，大動脈はほとんど造影されな い)を経験した，今回われわれはこの現象の原因をファントムを用い て検討した。

【方法】使用装置：GE横河製 1.0T Signa MR/i Hispeed ver8.3 M4 ファ ントム：仮想大動脈 $-500 \mathrm{ml}$ 生食水ボトルにGd-DTPAを $2 \mathrm{mmol} / /$ に調 製したもの 仮想内頸動脈一内径約 $1 \mathrm{~cm} の$ 試験管にGd-DTPAを $2 \mathrm{mmol} / /$ に調製したもの アクリル版に二つのファントムを固定して 撮影 使用シーケンス：3D FAST-TOF SPGR TR/TE/FA 6.1/Fr1.7/20 (1) 撮像開始から時間をずらしてファントムを撮影 $(0,1,2,3,4$ 秒). (2) conventional centric view orderとの比較検討.

【結果】(1)撮像開始から 2 秒ずらして, ファントムを撮像したとこ ろ, 大動脈ファントムに信号の抜けるアーチファクトが描出した. しかし内頸動脈ファントムには影響はなかった。（2）大動脈ファント ムは位相方向にぶれた画像となった.

【考察・まとめ】内頸動脈は大動脈よりも形状が細い。このため, 大 動脈のコントラストを司る低周波成分よりも，高周波側に位置して いる．したがって，撮像夕イミングが少しずれても描出が可能であ ると考えられた。逆に大動脈は内頸動脈より形状が太いため, 内頸 動脈のコントラストを司る低周波成分よりも低周波数側に位置して いる．したがって撮像夕イミングがずれると信号の抜けるアーチ ファクトが描出されると考えられた。この現象は従来法でも起こり 得るが，k-space中心部の取得効率が良いECVO法においてより目立 つものと思われた。

9 頸部動脈硬化症を有する患者のMRIによる血管壁厚の評価一頸 部エコーとの比較一

大阪警察病院・放射線技術科 四戸 徹, 佐々木次郎, 多賀井進 清本昌義，富永 聡，東出敏明

【目的】一般に動脈の狭窄には血栓やプラークによるものがあるが, 狭窄が起こる前には動脈硬化の状態がある.この時点で血管のリモ デリングにより血管壁が肥厚するといわれている．頸部血管は表在 性の血管でエコーにより評価可能だが冠動脈などの媣部血管には不 適当なため, 冠動脈の動脈硬化症を評価するためにMRIが有用では ないかと考えた，今回，その前段階として頸動脈の血管壁厚を測定 し，エコー所見との比較検討を行った.

【方法】頸部エコーにおける 3 点の中膜一内膜肥厚度 (IMT)の測定点 をMRA画像より推定し，その座標におけるMRI Ax画像( I 画像), お よびMRA Ax画像 (A 画像)を第 1 壁，第 2 壁，第 3 壁としてフィル ム出力した.フィルム上におけるI画像の直径を血管外径, $\mathrm{A}$ 画像 の直径を血管内径とし，その差分值を血管壁厚として測定し，それ ぞれを第 1 壁厚，第 2 壁厚，第 3 壁厚とした. そして，各壁厚と IMTとの相関評価, および第 1 壁厚から第 3 壁厚までの最大変化率 を求めることにより，血管壁厚を評価した.

【結果】血管壁厚とIMTの相関は第 1 壁厚で $\mathrm{R}=0.95$, 第 2 壁厚で $\mathrm{R}=0.94$ ，第 3 壁厚で $\mathrm{R}=0.98$ の相関があり，第 1 壁厚から第 3 壁厚ま での平均壁厚においても $\mathrm{R}=0.97$ 相関があった．また，最大変化率 はエコーで正常だった患者については $40 \%$ 以下，何らかの所見を有 した患者については $50 \%$ 以上と有意差があり，40\%を正常上限值と して用いることができると推察され，最大変化率が動脈硬化症の診 断の一指標となり得ることが示唆された. 